\title{
Reversible atrial gap junction remodeling during hypoxia/reoxygenation and ischemia: a possible arrhythmogenic substrate for atrial fibrillation
}

\author{
Anna Severino ${ }^{1 *}$, Maria L. Narducci ${ }^{1 *}$, Daniela Pedicino ${ }^{1}$, Vincenzo Pazzano ${ }^{1}$, Ada F. Giglio ${ }^{1}$, \\ Luigi M. Biasucci ${ }^{1}$, Giovanna Liuzzo ${ }^{1}$, Michela Casella ${ }^{2}$, Stefano Bartoletti ${ }^{2}$, Antonio Dello Russo ${ }^{2}$, \\ Gemma Pelargonio $^{1}$, Pasquale Santangeli ${ }^{3}$, Luigi Di Biase ${ }^{3}$, Andrea Natale $^{3}$ and Filippo Crea ${ }^{1}$ \\ ${ }^{1}$ Institute of Cardiology, Catholic University of Sacred Heart, Rome, Italy \\ ${ }^{2}$ Cardiac Arrhthymia Research Centre, Centro Cardiologico Monzino, Milano, Italy \\ ${ }^{3}$ Texas Cardiac Arrhythmia Institute ST David's Medical Center, Austin, USA
}

\begin{abstract}
Alteration of cardiomyocyte gap-junctions and component connexins ( $\mathrm{Cx}$ ) has been suggested to contribute to the development of atrial fibrillation (AF), including postoperative AF. We tested different possible stimuli, such as hypoxia and ischemia, influencing $\mathrm{Cx} 43$ and $\mathrm{Cx} 40$ expression and distribution in cultured atrial cells (HL-1) and reversibility of these processes after reoxygenation. Western-blot analysis and immunostaining using anti-Cx43, anti-Cx40 and anti-zonula occludens polyclonal antibodies were performed. HL-1 cells exposed to hypoxia for 24 and $48 \mathrm{~h}$ showed a reduction of $\mathrm{Cx} 43$ protein levels by $75 \%$ and $90 \%$ respectively $(p<0.001)$. During reoxygenation following $24 \mathrm{~h}$ of hypoxia, $\mathrm{Cx} 43$ levels increased to reach the basal level within $48 \mathrm{~h}$, while they remained at low level during reoxygenation following $48 \mathrm{~h}$ of hypoxia. Furthermore, atrial cardiomyocytes subjected to simulated ischemia (SI) were incubated in normoxic and hypoxic conditions for 3, 6, 9, $12 \mathrm{~h}$. Atrial cardiomyocytes subjected to SI in addition to normoxia showed a progressive reduction of $\mathrm{Cx} 43$ levels beginning from $3 \mathrm{~h}$. During SI and hypoxia, atrial Cx43 levels showed an initial decrease after $3 \mathrm{~h}$ with a subsequent rescue beginning from $6 \mathrm{~h}$ of exposure $(p=0.001)$. Hypoxia and ischemia per se downregulate $\mathrm{Cx} 43$ protein expression in atrial cardiomyocytes, but protein downregulation is reversible, depending on hypoxia duration and the association of the two triggers. These alterations characterize several conditions and might contribute to the generation of an arrhythmogenic substrate leading to AF onset and/or maintenance.
\end{abstract}

Key words: Atrial fibrillation - Connexins - Ischemia - Reoxygenation - Atrial cardiomyocytes

\section{Introduction}

Electrical remodeling, cardiac connexins and atrial fibrillation

Electrical remodeling plays a key role in the pathophysiology of atrial fibrillation (AF), the most common sustained arrhythmia (Nattel 2002, 2004). In this setting, alterations

Correspondence to: Maria Lucia Narducci, Institute of Cardiology, Catholic University of Sacred Heart, Largo A. Gemelli 8, 00135 Rome, Italy

E-mail: lianarducci@yahoo.it

*These authors contributed equally to this work. of cardiac connexins may be looked up as an important mechanism underlying the onset and/or the maintenance of the arrhythmia.

Cardiac connexins expression and distribution in atrial fibrillation

Beauchamp et al. (2006) demonstrated that connexins Cx40 and $\mathrm{Cx} 43$ play a key role in the propagation of atrial impulse. Some studies on human atrial samples of patients with chronic AF reported redistribution of $\mathrm{Cx} 43$ and $\mathrm{Cx} 40$ labeling towards the lateral borders of atrial myocytes and decreased levels of $\mathrm{Cx} 43$ per myocyte in both right atrial appendage and lateral 
free wall (Kostin 2001; Kanagaratnam et al. 2002; Takeuchi et al. 2006), as well as a reduction in $\mathrm{Cx} 40$ protein and mRNA levels (Nao et al. 2003; Wilhelm et al. 2006). On the other hand, some studies have reported increased Cx40 levels in patients with chronic AF (Polontchouk et al. 2001; Wetzel et al. 2005); consequently, data on this subject are still conflicting (Chaldoupi et al. 2009).

\section{Cx40 and Cx43 in postoperative AF}

Among the clinical spectrum of AF, those occurring in the postoperative period in patients undergoing coronary artery bypass grafting (CABG) are associated with a worse outcome (Maisel 2001), but the underlying mechanisms remain unclear. Alterations of gap junctions during bypass surgery, possibly triggered by an ischemic insult, may predispose to the occurrence of post-CABG AF (Yeh et al. 2002). Dupont et al. found increased Cx40 levels in atrial samples of patients with postoperative AF (Dupont et al. 2001), but in a more recent study $\mathrm{Cx} 43$ and $\mathrm{Cx} 40$ proteins have been found significantly reduced in patients undergoing cardioplegic cardiac arrest during CABG surgery (Li 2009).

\section{Aim of the study}

While regulation of ventricular connexin has been investigated in several in vitro models, atrial connexin have been poorly investigated (Beauchamp et al. 2006). In this study, we evaluated connexin expression and distribution in atrial cardiomyocytes (HL-1 cells) and the effects of hypoxia/reoxygenation, ischemia in association with normoxia and hypoxia, pro-inflammatory stimuli, neurotransmitters and angiotensin II (Ang II) on Cx43 and Cx40 in the same cells. These cells, derived from mouse atrial cardiomyocytes, retain morphological, biochemical, and electrophysiological properties of differentiated atrial cardiomyocytes (Claycomb et al. 1998; White 2004).

\section{Materials and Methods}

\section{Culture of HL-1 cells}

HL-1 cells were cultured in Claycomb medium (JRH Biosciences) supplemented with 10\% FBS (JRH Biosciences), L-glutamine $2 \mathrm{mM}$, norepinephrine $0.1 \mathrm{mM}$ and penicillin/streptomycin $100 \mathrm{U} / \mathrm{ml} 100 \mu \mathrm{g} / \mathrm{ml}$.

\section{Cell exposure to hypoxia and reoxygenation}

Subconfluent cells were maintained in a humidified incubator in $21 \% \mathrm{O}_{2}$ (normoxia) or in a humidified sealed chamber (Billups-Rothenburg, Del Mar, CA) gassed with 3\% $\mathrm{O}_{2}$ (hypoxia) for 2, 4, 6, 16, 20, 24 and $48 \mathrm{~h}$. After 24 and $48 \mathrm{~h}$ of hypoxia, HL-1 cells were replaced in normoxia conditions for $8,24,30$ and $48 \mathrm{~h}$ (reoxygenation). A total of five experiments were carried out for each time.

\section{Cell exposure to simulated ischemia}

The cells were subjected to simulated ischemia for 3, 6, 9 and $12 \mathrm{~h}$, by replacing the cell medium with an "ischemia buffer" that contained (in mM): $\mathrm{NaCl} 118, \mathrm{NaHCO}_{3} 24, \mathrm{NaH}_{2} \mathrm{PO}_{4} 1$,
A

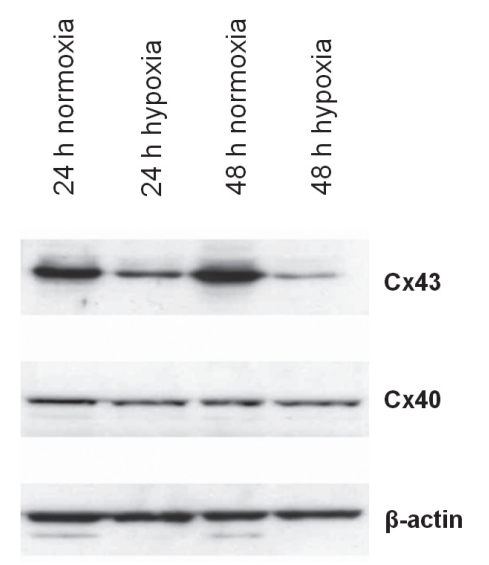

B

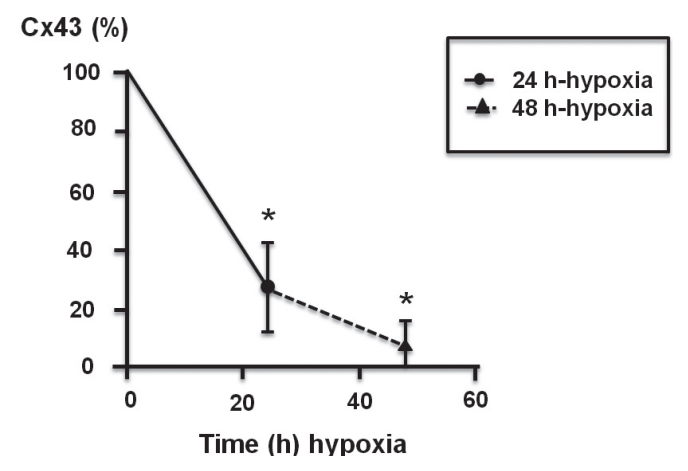

Figure 1. Effects of hypoxia on $\mathrm{Cx} 43$ and $\mathrm{Cx} 40$ protein expression in atrial cells. A. Representative blots for the exposure times (24 and $48 \mathrm{~h}$ ), showing pairs of normoxic and hypoxic samples. Equivalency of loading was verified with an antibody against $\beta$-actin. B. Quantitative densitometric analysis of $\mathrm{Cx} 43$ protein at different time points $(0,24,48 \mathrm{~h}$ of hypoxia). Each value was divided by its corresponding $\beta$-actin value. Values were normalized to control (normoxic cultures) values, which were set as $100 .^{*} p<0.001$, at 24 and $48 \mathrm{~h}$ of hypoxia as compared to normoxic cultures. Data are means \pm SE; $n=5$. 
$\mathrm{CaCl}_{2}-2 \mathrm{H}_{2} \mathrm{O} 2.5, \mathrm{MgCl}_{2} 1.2$, sodium lactate $20, \mathrm{KCl} 16,2$ deoxyglucose 10 ( $\mathrm{pH}$ adjusted to 6.2). Contemporaneously, the cells were incubated at $37^{\circ} \mathrm{C}$ in normoxic $\left(21 \% \mathrm{O}_{2}\right)$ and hypoxic $\left(3 \% \mathrm{O}_{2}\right)$ conditions during the entire simulated ischemia period.

Cell incubation with $C$-reactive protein, cytokines, neurotransmitters and angiotensin II

HL- 1 cells were treated with 1, 5, 10, 20 and $50 \mathrm{ng} / \mathrm{ml}$ of human recombinant (hr) C-reactive protein (CRP; Calbiochem, San Diego, CA), with hr interleukins IL-6 and IL-12 (1, 10, $100 \mathrm{ng} / \mathrm{ml}$ ) (Biodesign, Saco, ME), hr tumor necrosis factor-alpha (TNF- $\alpha)(1,5,10 \mathrm{ng} / \mathrm{ml})$ (Biodesign, Saco, ME), acetylcholine (Ach) and epinephrine (Epi) (Sigma-Aldrich) $(1,10,100 \mu \mathrm{M})$ or hr angiotensin II (Ang II) (Sigma-Aldrich) $(0.01,0.1,1 \mu \mathrm{M})$ for 24 and $48 \mathrm{~h}$. A total of three experiments were carried out for each time.

\section{RNA extraction and $q R T-P C R$}

Total RNA was extracted from HL-1 cells by using Trizol reagent (Invitrogen). $0.5 \mu \mathrm{g}$ of total RNA was reverse transcribed by iScript cDNA synthesis kit (Biorad). Quantitative polymerase chain reaction (qPCR) was performed by SYBR Green method on an iQ5 Real Time instrument (Biorad). The results were normalized for the $\beta$-actin housekeeping gene.

\section{Cx43 and Cx40 expression}

HL-1 cells were lysed in lysis buffer (in $\mathrm{mM}$ ): Tris- $\mathrm{HCl} 50$ (pH 7.4), EDTA 5, NaCl 250, NaF 50, 0.1\% Triton X-100,
$\mathrm{Na}_{3} \mathrm{VO}_{4}$ 0.1, phenylmethylsulfonyl fluoride 1 , and $10 \mu \mathrm{g} / \mathrm{ml}$ leupeptin; for $30 \mathrm{~min}$ on ice. Lysates were centrifuged at $14,000 \times g$ for $10 \mathrm{~min}$ at $4^{\circ} \mathrm{C}$. Proteins were resolved through $10 \%$ acrylamide SDS-PAGE, transferred to polyvinylidene difluoride membranes and probed with anti-Cx40 (C-20), anti-Cx43 (H-150) polyclonal antibodies (Santa Cruz) and anti- $\beta$-actin (clone AC-74) monoclonal antibody (SigmaAldrich). To detect the phosphorylated forms of $\mathrm{Cx} 43$ the following antibodies were used: anti-Cx43 (Tyr 265) and anti-Cx43 (Ser 279/282) polyclonal antibodies (Santa Cruz).

\section{Cx43 distribution in cardiomyocytes}

HL-1 cells were grown on gelatin/fibronectin-coated coverslips and were fixed with $4 \%$ paraformaldehyde in PBS ( $\mathrm{pH}$ 7.2) for $15 \mathrm{~min}$ at room temperature. The fixed cells were permeabilized with PBS/1\% TRITON X-100 for $5 \mathrm{~min}$ and were immunostained with the following primary antibodies: rabbit polyclonal anti-Cx43 antibodies (Santa Cruz) and anti-zonula occludens (ZO-1) (clone 1A12, Zymed). Incubation with fluorescein-conjugated antibodies was performed. Samples were examined by qualitative immunofluorescence on Olympus confocal laser scanning microscope.

\section{Statistics}

Data were expressed as mean \pm SEM. Normality of data was assessed by Kolmogorov-Smirnov test. Differences were analyzed with the one way-repeated measures ANOVA using Greenhouse-Jeisser post-hoc testing. A value of $p<0.05$ was
A

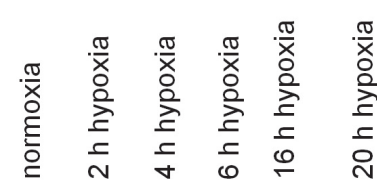
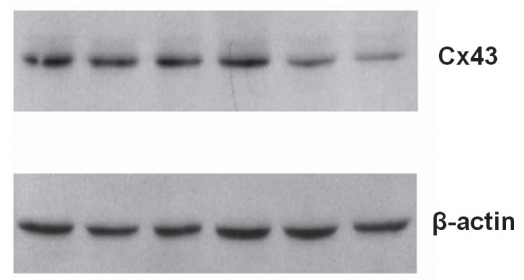

B

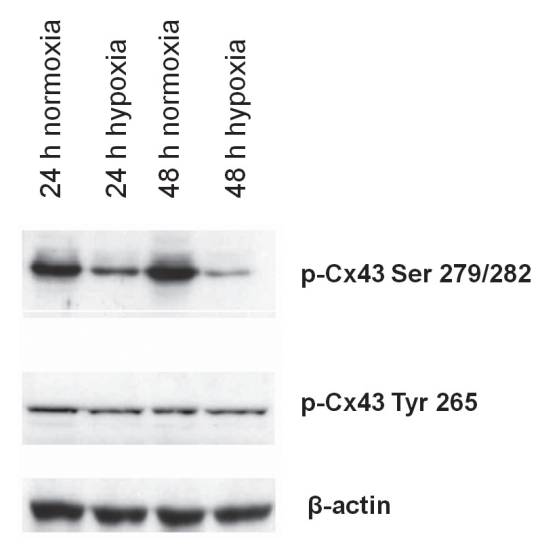

Figure 2. Time-dependent effect of hypoxia on total $\mathrm{Cx} 43$ protein levels and $\mathrm{Cx} 43$ phosphorylated isoforms in atrial cells. A. Representative blots for each of the exposure times of 2, 4, 6, 16 and $20 \mathrm{~h}$ hypoxia and for normoxia. Equivalency of loading was verified with an antibody against $\beta$-actin. Total of three experiments was performed, with similar results. B. Effects of 24 and 48 h of hypoxia on phosphorylated isoforms of Cx43. Representative blots for the exposure times ( 24 and $48 \mathrm{~h}$ ), showing pairs of normoxic and hypoxic samples of Ser 279/282 and Tyr 265 phosphorylated Cx43 (p-Cx43). Equivalency of loading was verified with an antibody against $\beta$-actin (lower panel). Total of 3 experiments was performed, with similar results. 


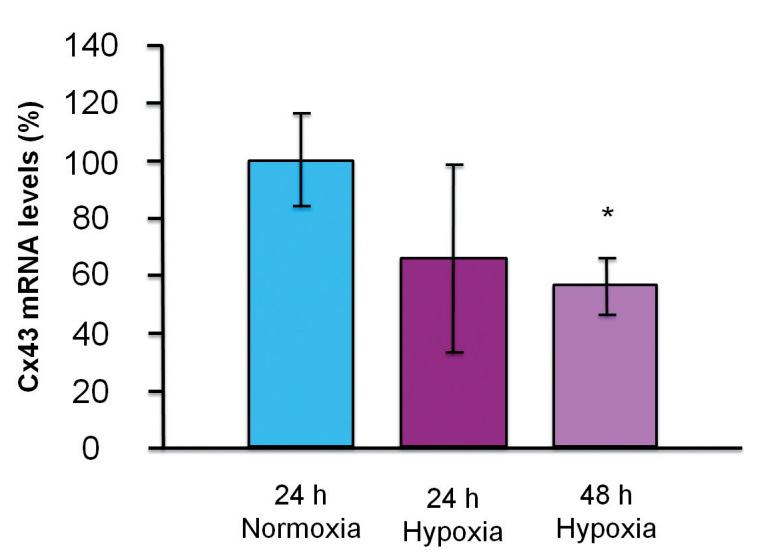

Figure 3. The effect of 24 and $48 \mathrm{~h}$ of hypoxia on Cx43 mRNA levels in atrial cells. Quantitative analysis of Cx43 mRNA. Atrial cells cultures were exposed to normoxia for $24 \mathrm{~h}$ (blue column), to hypoxia for $24 \mathrm{~h}$ (purple column) and $48 \mathrm{~h}$ (lilac column). Cx43 mRNA was analyzed using RT-PCR. Each value was divided by its corresponding $\beta$-actin value. Values are normalized to control values (normoxic cultures), which were set as $100 \% .{ }^{*} p=0.007$, compared to control.

considered significant. Statistical analysis was performed with SPSS software (ver. 15) and graphics were performed using Graph Pad software.
Results

\section{Effects of hypoxia on Cx43 and Cx40}

\section{Cx43 levels}

In Claycomb atrial cells, total Cx43 protein levels at 24 and $48 \mathrm{~h}$ of hypoxia decreased to $27 \pm 5 \%(p<0.001)$ and to $8 \pm 4 \%(p<0.001)$ of the normoxic level, respectively (Fig. $1 \mathrm{~A}, \mathrm{~B}$ ). As seen by representative blots (Fig. 2A), the effect of hypoxia on $\mathrm{Cx} 43$ protein levels was time-dependent. Beginning from $16 \mathrm{~h}$ of hypoxia, there was a significant reduction in total $\mathrm{Cx} 43$, protein levels decreased to $50 \pm 5 \%$ $(p=0.02)$. Of note, during hypoxia the two phosphorylated isoforms of Cx43 (279/282 Ser- and 265 Tyr-phosphorylated Cx43) showed different trends: 279/282 Ser-phosphorylated Cx43 levels at 24 and $48 \mathrm{~h}$ of hypoxia decreased to $53 \pm 5 \%$ $(p=0.003)$ and $20 \pm 3 \%(p<0.001)$ respectively, while 265 Tyr-phosphorylated Cx43 levels remained permanently unchanged (Fig. 2B). Thus, in atrial cardiomyocytes the reduction of $\mathrm{Cx} 43$ protein levels during hypoxia was primarily caused by a reduction of the Ser-phosphorylated isoform. Similarly, Cx43 mRNA levels decreased to $61 \pm 0.4 \%$ (non significant) at $24 \mathrm{~h}$ of hypoxia and to $55 \pm 0.1 \%$ at $48 \mathrm{~h}$ ( $p=$ 0.007), suggesting that long-term changes in $\mathrm{Cx} 43$ protein expression occurred also at a transcriptional level (Fig. 3).

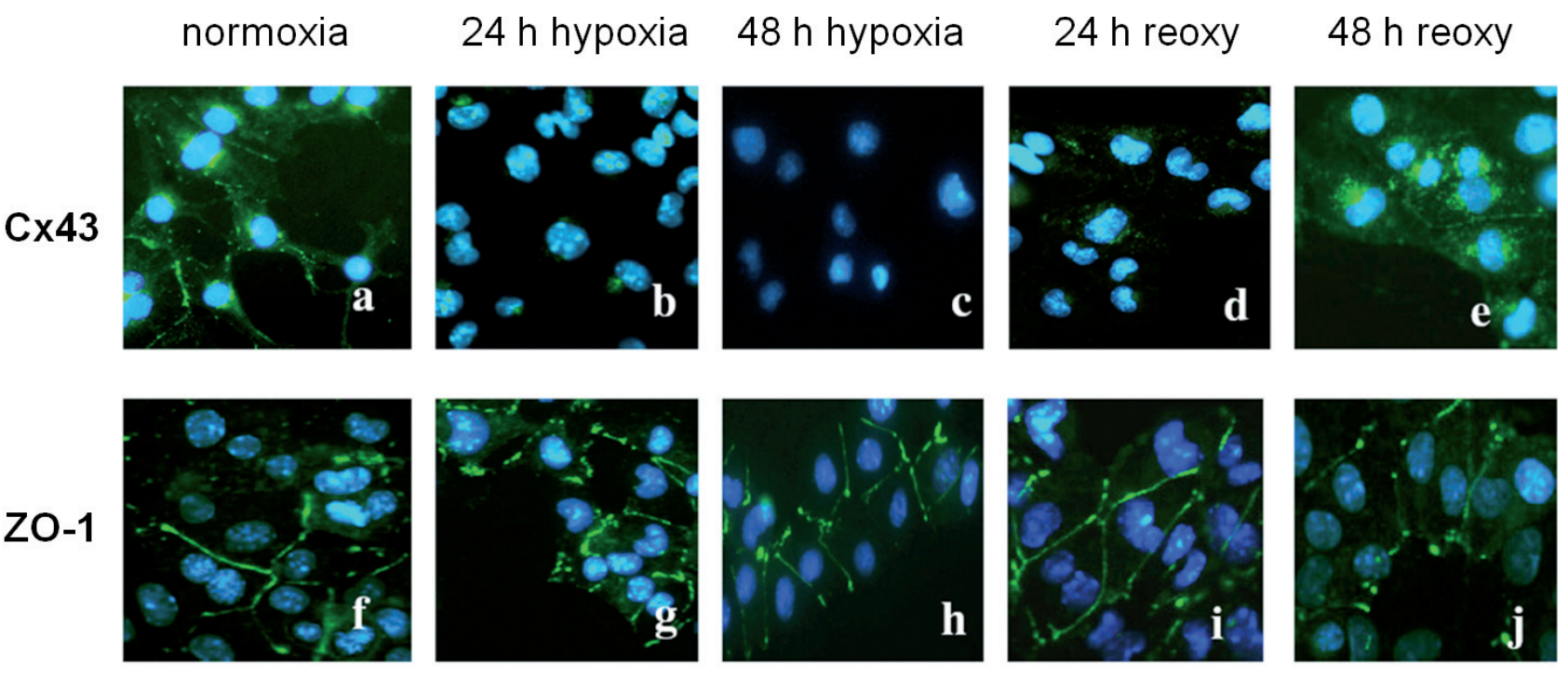

Figure 4. Immunofluorescence microscopy of HL-1 cells subjected to normoxia, 24 and $48 \mathrm{~h}$ of hypoxia, 24 and $48 \mathrm{~h}$ of reoxygenation (reoxy) after $24 \mathrm{~h}$ of hypoxia. Immunostaining with polyclonal anti-Cx43 and anti-ZO-1 antibodies was performed (green fluorescence). Immunoreactive signal for $\mathrm{Cx} 43$ was concentrated in discrete spots at sites of intercellular apposition and in the cytoplasm (a). Immunoreactive signal for ZO-1 was concentrated solely at cell membranes (f). After $24 \mathrm{~h}(\mathbf{b})$ and $48 \mathrm{~h}(\mathbf{c})$ of hypoxia, green Cx43 staining was dramatically lost, while the intensity of ZO-1 in HL-1 cells was found to be unaltered after hypoxia ( $\mathbf{g}, \mathbf{h})$ as compared to normoxic cells (f). Only after $48 \mathrm{~h}$ of reoxygenation (e), but not after $24 \mathrm{~h}$ (d), Cx43 immunoreactive signal reached basal levels. The intensity of ZO-1 in HL-1 cells subjected to 24 (i) and $48 \mathrm{~h}$ (j) of reoxygenation was apparently similar to normoxic atrial myocytes. Nuclei were stained blue with DAPI. 
A

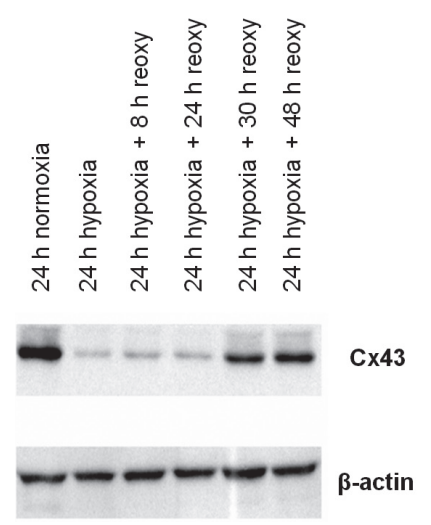

B

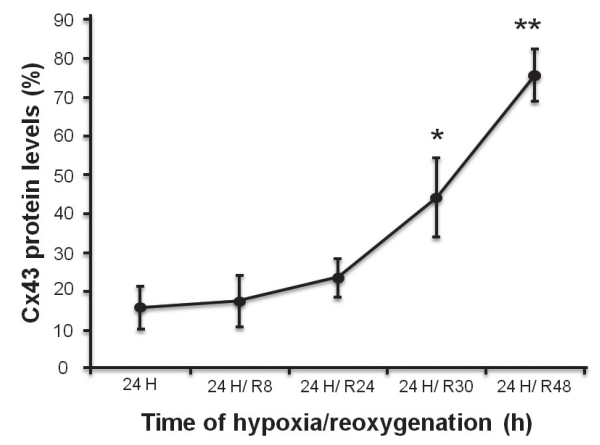

Figure 5. Effect of reoxygenation on $\mathrm{Cx} 43$ protein levels after $24 \mathrm{~h}$ of hypoxia. A. After $24 \mathrm{~h}$ hypoxia, atrial cells were exposed to 8, 24, 30 and $48 \mathrm{~h}$ of reoxygenation (reoxy). Equivalency of loading was verified with an antibody against $\beta$-actin. B. Quantitative densitometric analysis of $\mathrm{Cx} 43$ protein at the time-points considered $(24 \mathrm{~h}$ hypoxia $(\mathrm{H})$ followed by $8,24,30$ and 48 h reoxygenation (R). Each value was divided by its corresponding $\beta$-actin value. Values were normalized to control (normoxic cultures) values, which were set as 100. ${ }^{\star} p=0.05,{ }^{* *} p=0.001$, compared to $24 \mathrm{~h}$ hypoxia. Data are means $\pm \mathrm{SE} ; n=5$.

\section{Cx43 distribution}

Figure 4 shows representative images of atrial cells during normoxia and after 24 and $48 \mathrm{~h}$ of hypoxia obtained by confocal microscope. In normoxic cells intense $\mathrm{Cx} 43$ immunostaining was concentrated in discrete spots on intercellular apposition and in the cytoplasm (Fig. 4a). In contrast, signal for $\mathrm{Cx} 43$ was substantially absent in atrial cells subjected to 24 or $48 \mathrm{~h}$ of hypoxia (Fig. 4b, c). Of note, ZO-1 was homogeneously distributed on cellular membranes of normoxic atrial myocytes, while it was absent in the cytoplasm (Fig. 4f). The intensity of ZO-1 after 24 or $48 \mathrm{~h}$ of hypoxia was found to be unaltered as compared to normoxic atrial cells (Fig. 4g, h).

\section{Cx40 levels}

Hypoxia did not significantly affect $\mathrm{Cx} 40$ protein levels in atrial cells (Fig. 1A).

\section{Effects of reoxygenation on Cx43 protein levels}

After $24 \mathrm{~h}$ of hypoxia, total Cx 43 protein levels increased gradually during reoxygenation to reach the basal level within $48 \mathrm{~h}(p=0.001)$ (Fig. 5A, B). Accordingly, immunofluorescence analysis for $\mathrm{Cx} 43$ in atrial myocytes subjected to $24 \mathrm{~h}$ of hypoxia confirmed that $\mathrm{Cx} 43$ protein downregulation was reversible after $48 \mathrm{~h}$ of reoxygenation (Fig. 4e). In contrast, $\mathrm{Cx} 43$ protein levels remained

B

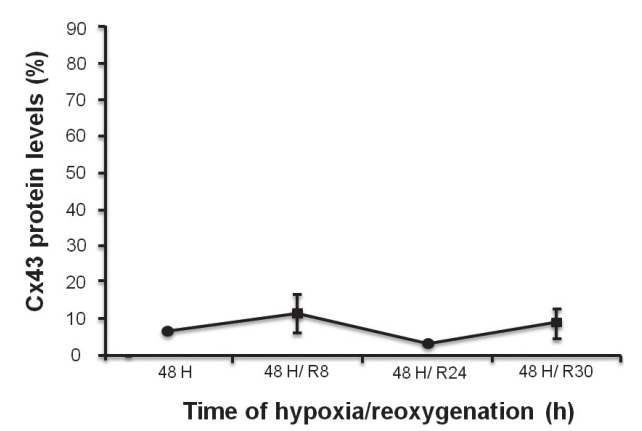

Figure 6. Effect of reoxygenation on Cx43 protein levels after $48 \mathrm{~h}$ of hypoxia. A. After $48 \mathrm{~h}$ hypoxia, atrial cells were exposed to 8, 24, and $30 \mathrm{~h}$ of reoxygenation (reoxy). $48 \mathrm{~h}$ of reoxygenation after $48 \mathrm{~h}$ of hypoxia were not included for high atrial cell mortality rate. B. Quantitative densitometric analysis of $\mathrm{Cx} 43$ protein at the time-points considered $(48 \mathrm{~h}$ hypoxia $(\mathrm{H})$ followed by 8,24 and $30 \mathrm{~h}$ reoxygenation $(\mathrm{R})$ ). Each value was divided by its corresponding $\beta$-actin value. Values were normalized to control (normoxic cultures) values, which were set as 100 . There was no statistically significant change of $\mathrm{Cx} 43$ protein levels in atrial cells exposed to reoxygenation after $48 \mathrm{~h}$ of hypoxia. Data are means \pm SE; $n=5$. 
unchanged during reoxygenation after $48 \mathrm{~h}$ of hypoxia (Fig. 6A, B).

\section{Effects of simulated ischemia on Cx43 protein levels}

Atrial cells subjected to simulated ischemia and incubated in normoxic conditions showed a progressive reduction of Cx43 levels (Fig. 7). Particularly, after $3 \mathrm{~h}$ of exposure, the quantity of $\mathrm{Cx} 43$ protein was decreased to $41 \pm 14 \%$ to reach a plateau $(18 \pm 8 \%)$ after $6 \mathrm{~h}$ of simulated ischemia. Surprisingly, atrial cells subjected to simulated ischemia and incubated in hypoxic condition showed an inverse trend with an initial decrease of $\mathrm{Cx} 43$ levels to $58 \pm 20 \%$ after $3 \mathrm{~h}$ of treatment and a subsequent upregulation of $\mathrm{Cx} 43$ levels beginning from $6 \mathrm{~h}(66 \pm 29 \%)$ up to $12 \mathrm{~h}(90 \pm 39 \%)$ of exposure ( $p=0.001$; Fig. 7$)$.

\section{Effects of cell incubation with CRP, cytokines, neurotransmitters and Ang II}

Incubation with increasing concentrations of CRP, IL-6, IL12 and TNFa did not affect $\mathrm{Cx} 43$ and $\mathrm{Cx} 40$ protein levels. Similarly, incubation with increasing concentrations of Ach and Epi or Ang II for 24 and $48 \mathrm{~h}$ did not alter $\mathrm{Cx} 43$ and Cx40 protein levels.

\section{Discussion}

Hypoxia/reoxygenation and connexin remodeling: CX43 modulation

Hypoxic-ischemic injury is one of the most studied triggers of connexin remodeling, which in turn is a possible contributing factor to the occurrence of AF (Kanagaratnam et al.
2002). While previous studies assessed connexin modulation only in ventricular myocytes (Beardslee et al. 2000; Kostin 2001; Zeevi-Levin et al. 2005; Matsuschita et al. 2006), this is the first study on connexin remodeling in adult atrial cells, showing that both hypoxia and ischemia are potent modulator of $\mathrm{Cx} 43$ redistribution and that the latter can be, in some cases, reversible. In the first part of our study, we observed a significant downregulation of $\mathrm{Cx} 43$ expression in atrial cells during hypoxia, confirmed by Western Blot analysis and qualitative immunofluorescence, demonstrating at the same time how the hypoxic insult acts specifically on $\mathrm{Cx} 43$, since qualitative immunofluorescence did not confirm the same trend for ZO-1, an essential constituent of intercalated disk required for the proper formation of $\mathrm{Cx} 43$ gap junctions (Laing et al. 2007; Palatinus et al. 2011), and for Cx40 protein levels. Moreover, we found that $\mathrm{Cx} 43$ protein downregulation in atrial cells during hypoxia is time-dependent, associated with a parallel Cx43 mRNA decrease. Finally, Cx43 protein level reduction after $24 \mathrm{~h}$ of hypoxia reversed to almost the pre-hypoxic value during reoxygenation, while the reduction after $48 \mathrm{~h}$ of hypoxia was irreversible. The loss of reversibility of $\mathrm{Cx} 43$ downregulation after $48 \mathrm{~h}$ of hypoxia followed by reoxygenation was probably due to a high apoptotic rate of HL-1 atrial cells induced by long-term hypoxia. The aforementioned data can be partially confirmed by several studies in ventricular myocytes. Zeevi-Levin et al. (2005) demonstrated that $5 \mathrm{~h}$ of hypoxia decreased $\mathrm{Cx} 43$ protein in rat ventricular myocytes, without a concurrent reduction of mRNA levels. In our study, Cx43 mRNA downregulation at $48 \mathrm{~h}$ of hypoxia in atrial cells could be explained by specific regulation of connexins in different species (rat versus mouse) and tissues (ventricle versus atrium) (Kostin 2001). In keeping with our data in atrial cells, $\mathrm{ZO}-1$ ventricular sarcolemmal expression did not change during hypoxic condition and hypoxia-induced effects on ventricular $\mathrm{Cx} 43$
A

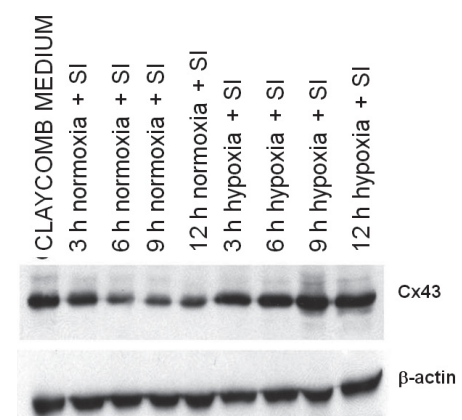

B

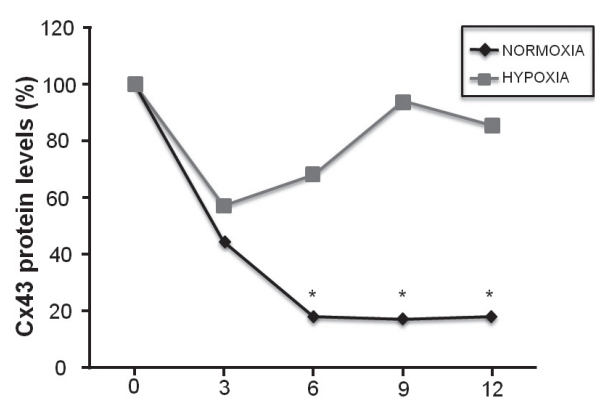

Figure 7. Cx43 protein expression during simulated ischemia (SI). A. blots for the exposure times of 3, 6, 9 and $12 \mathrm{~h}$ for samples incubated respectively in normoxic and hypoxic conditions. Equivalency of loading was verified with an antibody against $\beta$-actin. B. Quantitative densitometric analysis of Cx43 protein in HL-1 cells cultured in the same experimental conditions as in A. After $6 \mathrm{~h}$ of normoxia, total Cx43 protein level was significantly reduced in HL-1 cells treated with SI $(p=0.001)$, but $\mathrm{Cx} 43$ protein level did not change during hypoxia + SI treatment. In addition to SI, hypoxia could inhibit the downregulation of $\mathrm{Cx} 43$ protein and could be considered as a cytoprotective mechanism induced by oxidative stress. ${ }^{*} p=0.001 ; n=5$. 
protein level were reversed by reoxygenation (Matsuschita et al. 2006). Moreover, as previous studies in ischemic ventricular myocytes demonstrated (Beardslee et al. 2000; Matsuschita et al. 2006), in our study atrial cardiomyocytes exhibited a progressive reduction of Ser-phosphorylated $\mathrm{Cx} 43$. Of note, the loss of serine phopshorylation and the gain of tyrosine phosphorylation have been associated with loss of cell-cell coupling (Lau et al. 1996; Zhou 1999; Barker 2002; Tepass 2002; Kieken et al. 2009). At this regard, our study could be a further confirmation of atrial intercellular uncoupling arising from hypoxic insults, but studies on functional gap junction coupling will be needed to confirm this hypothesis.

\section{Role of hypoxia and/or ischemia in Cx43 regulation}

In order to further clarify the role of hypoxic-ischemic insult on gap junction activity, we tested the effects of ischemia associated with normoxia and hypoxia on atrial cells. Ischemia is indeed a complex condition involving not only hypoxia, but also a build-up of toxic metabolites, acidosis and energy substrates depletion. This pathophysiological setting, characterized not only by oxygen deprivation but also by metabolic stress, occurs in several cardiac pathological conditions, and could also be considered as an in vitro replication of cardioplegic arrest during cardiac surgery (Anselmi et al. 2004). In our study, atrial cells subjected to ischemia and incubated in normoxic conditions showed Cx43 downregulation as atrial cells exposed only to hypoxia. In contrast to this trend, atrial cells subjected to ischemic and hypoxic insult showed an initial decrease of Cx43 levels with subsequent rescue of protein levels beginning from $6 \mathrm{~h}$ of exposure. These data highlight the time dependence of $\mathrm{Cx} 43$ modulation during the association of hypoxic and ischemic insult. Although this different trend needs to be proved in electrophysiological studies assessing Cx43 hypoxia/ischemia-induced modulation, several studies on neuronal activity provided a functional explanation of an increased Cx43 expression during hypoxia/ischemia (Nakase 2003, 2006; Jaderstad 2010; Orellana et al. 2010). Lin et al. (1998) demonstrated that astrocytes subjected to ischemic stimuli can increase the density and the number of sarcolemmal gap junctions with consequent spreading of toxic metabolities to the neighboring unaffected cells. The different responses to hypoxic and/or ischemic stimuli by atrial cells are strongly dependent by the quality of the insult. We could hypothesize that in the first hours of ischemic stress, the downregulation of $\mathrm{Cx} 43$ protein may represent the consequence of hypoxic state (Schulz et al. 2007; Srisakuldee et al. 2009; Mühlfeld et al. 2010). A persistent ischemic stress could upregulate $\mathrm{Cx} 43$, promoting the spreading of the ischemic insult in neighboring unaffected cells (Andrade-Rozental et al. 2000; Frantseva et al. 2002a,b; Cusato et al. 2003; de Pina-Benabou et al. 2005; Talhouk et al. 2008).

\section{Myocardial hypoxia/ischemia and atrial fibrillation}

Several studies have shown the role of myocardial ischemia in the pathogenesis of AF. It has been proved that atrial ischemia promotes AF in dogs (Sinno et al. 2003). In patients with lone AF, Skalidis et al. (2008) demonstrated isolated atrial microvascular perfusion abnormalities. Moreover, it has been recently demonstrated that coronary disease involving the atrial branches (e.g. right coronary atrial branch and left circumflex atrial branch) is an independent predictor for the development of AF early after an acute myocardial infarction, even after adjustment for age, gender, left ventricular ejection fraction and filling pressure, left atrium size, time to reperfusion and TIMI flow after percutaneous revascularization (Alasady et al. 2011). Ahlsson et al. showed a significant correlation between postoperative AF and ischemic myocardial injury assessed by CK-MB (creatin kinase isoenzyme MB) values (Ahlsson et al. 2007). Accordingly, in a prospective observational study, postoperative AF was associated with a lower rate of preoperative therapy with beta-blockers, possibly because of their anti-ischemic effect (Mathew et al. 2004). Particularly, during cardiac surgery with cardiopulmonary bypass and cardioplegic arrest, downregulation of atrial gap junctions (Cx43 and Cx40) occurred (Yeh et al. 2002; Li 2009), while in another study higher levels of $\mathrm{Cx} 40$ expression were found in patients that subsequently developed AF (Dupont et al. 2001).

Cx43 is well expressed in atrial myocardial tissue (Vozzi et al. 1999). Several studies on Cx43 expression in human and animal models of AF yielded conflicting results, demonstrating both increased and decreased Cx43 levels (Elvan et al. 1997; Kostin et al. 2002). Similarly, studies on Cx40 expression in AF have also obtained controversial data (Dupont et al. 2001; Kostin et al. 2002; Chaldoupi et al. 2009). The reasons underlying these differences are probably multiple, including study on various animal models and patients with AF of different aetiology, analysis of different myocardial regions (e.g. atrial versus ventricular tissue, left atrium versus right atrium), and lack of distinction between gap junction alterations inducing AF or provoked by the arrhythmia itself. Concerning the results of our study, we could hypothesize that the stimuli we used may act differently on connexin expression, modulating Cx43 while Cx40 could be influenced by other conditions not tested in the present study. A recent study on animals suggest that downregulation of $\mathrm{Cx} 43$ is of major importance in determining myocardial susceptibility to AF development (Bikou et al. 2011), although this finding needs further validation in humans. 


\section{Inflammatory stimuli and connexin expression}

As inflammation of atrial tissue has been documented in patients with AF (Boos 2006), we studied also the effect of pro-inflammatory cytokines and CRP as potential regulators of connexin expression in atrial cells. We failed to find changes in $\mathrm{Cx} 43$ and $\mathrm{Cx} 40$ protein expression after incubation with increasing concentrations of CRP, IL-6, IL-12 and TNF alpha. Cx43 and Cx40 protein levels did not change either after incubation with Ach, Epi or Ang II. In the particular setting of postoperative AF, the possible relation between this arrhythmia and CRP levels has been studied with conflicting results (Amar et al. 2005; Fontes et al. 2005; Lo et al. 2005; Hogue et al. 2006) and recent evidence suggests no correlation between preoperative and postoperative CRP concentrations and postoperative AF, while a significant correlation was found between ischemic myocardial injury assessed by postoperative CK-MB values (Ahlsson et al. 2007).

\section{Effect of Ang II on atrial connexin expression}

Current clinical evidence suggests a role of renin-angiotensin system blockade in the prevention of AF (Jibrini 2008). In this study, we failed to find changes in atrial connexin expression after treatment with Ang II, while, in ventricular myocytes, Ang II increased Cx43 expression level (Polontchouk et al. 2002). Thus, the therapeutic effects of angiotensin-converting enzyme inhibitors or angiotensin receptor blockers on AF could be mediated by molecular pathways not involving connexin expression.

\section{Conclusion}

Alterations of intercellular communication through gap junctional connections are likely to play an important role in the pathogenesis of AF. We used a cell model of differentiated atrial cardiomyocytes to investigate the role of potential modulators of connexin remodeling. We found that hypoxia and ischemia are potent modulators of $\mathrm{Cx} 43$ expression at both translational and transcriptional levels, without any detectable effect on $\mathrm{Cx} 40$ protein levels. Thus, atrial $\mathrm{Cx} 43$ downregulation might be independently induced by hypoxia and ischemia and might be reversible after reoxygenation. Prolonged hypoxic-ischemic insult upregulate Cx43 protein levels with a rescue to baseline levels. These different responses to hypoxia and ischemia by atrial Cx43 could be partially responsible of gap junction alterations observed in AF.

Acknowledgements. We appreciate the technical assistance of Dr. Giuliana Di Rocco and Dr. Antonio Gabriele. Partially supported by the FIC (Federazione Italiana Cardiologia) (grant SANOFI AVENTIS/FIC December 2007).

\section{References}

Ahlsson A. J., Bodin L., Lundblad O. H., Englund A. G. (2007): Postoperative atrial fibrillation is not correlated to C-reactive protein. Ann. Thorac. Surg. 83, 1332-1337 http://dx.doi.org/10.1016/j.athoracsur.2006.11.047

Alasady M., Abhayaratna W. P., Leong D. P., Lim H. S., Abed H. S., Brooks A. G., Mattchoss S., Roberts-Thomson K. C., Worthley M. I., Chew D. P., Sanders P. (2011): Coronary artery disease affecting the atrial branches is an independent predictor of atrial fibrillation after myocardial infarction. Heart Rhythm 8, 955-960 http://dx.doi.org/10.1016/j.hrthm.2011.02.016

Amar D., Zhang H., Heerdt P. M., Park B., Fleisher M., Thaler H. T. (2005): Statin use is associated with a reduction in atrial fibrillation after noncardiac thoracic surgery independent of C-reactive protein. Chest 128, 3421-3427 http://dx.doi.org/10.1378/chest.128.5.3421

Andrade-Rozental A. F., Rozental R., Hopperstad M. G., Wu J. K., Vrionis F. D., Spray D. C. (2000): Gap junctions: the, 'kiss of death" and ,'the kiss of life". Brain Res. Brain Res. Rev. 32, 308-315 http://dx.doi.org/10.1016/S0165-0173(99)00099-5

Anselmi A., Abbate A., Girola F., Nasso G., Biondi-Zoccai G. G., Possati G., Gaudino M. (2004): Myocardial ischemia, stunning, inflammation, and apoptosis during cardiac surgery: a review of evidence. Eur. J. Cardiothorac. Surg. 25, 304-311 http://dx.doi.org/10.1016/j.ejcts.2003.12.003

Barker R. J., Price R. L., Gourdie R. G. (2002): Increased association of ZO-1 with connexin 43 during remodeling of cardiac gap junctions. Circ. Res. 90, 317-324 http://dx.doi.org/10.1161/hh0302.104471

Beardslee M. A., Lerner D. L., Tadros P. N., Laing J. G., Beyer E. C., Yamada K. A., Kléber A. G., Schuessler R. B., Saffitz J. E. (2000): Dephosphorylation and intracellular redistribution of ventricular connexin 43 during electrical uncoupling induced by ischemia. Circ. Res. 87, 656-662 http://dx.doi.org/10.1161/01.RES.87.8.656

Beauchamp P., Yamada K. A., Baertschi A. J., Green K., Kanter E. M., Saffitz J. E., Kléber A. G. (2006): Relative Contributions of Connexins 40 and 43 to atrial impulse propagation in synthetic strands of neonatal and fetal murine cardiomyocytes. Circ. Res. 99, 1216-1224 http://dx.doi.org/10.1161/01.RES.0000250607.34498.b4

Bikou O., Thomas D., Trappe K., Lugenbiel P., Kelemen K., Koch M., Soucek R., Voss F., Becker R., Katus H. A., Bauer A. (2011): Connexin 43 gene therapy prevents persistent atrial fibrillation in a porcine model. Cardiovasc. Res. 92, 218-225 http://dx.doi.org/10.1093/cvr/cvr209

Boos C. J., Anderson R. A., Lip G. Y. (2006): Is atrial fibrillation an inflammatory disorder? Eur. Heart J. 27, 136-149 http://dx.doi.org/10.1093/eurheartj/ehi645

Chaldoupi S. M., Loh P., Hauer R. N., de Bakker J. M., van Rijen H. V. (2009): The role of connexin40 in atrial fibrillation. Cardiovascular Res. 84, 15-23 http://dx.doi.org/10.1093/cvr/cvp203 
Claycomb W. C., Lanson N. A. Jr, Stallworth B. S., Egeland D. B., Delcarpio J. B., Bahinski A., Izzo N. J. Jr. (1998): HL-1 cells: A cardiac muscle cell line that contracts and retains phenotypic characteristics of the adult cardiomyocytes. Proc. Natl. Acad. Sci. U. S. A. 95, 2979-2984 http://dx.doi.org/10.1073/pnas.95.6.2979

Cusato K., Bosco A., Rozental R., Guimarães C. A., Reese B. E., Linden R., Spray D. C. (2003): Gap junctions mediate bystander cell death in developing retina. J. Neurosci. 23, 6413-6422

de Pina-Benabou M. H., Szostak V., Kyrozis A., Rempe D., Uziel D., Urban-Maldonado M., Benabou S., Spray D. C., Federoff H. J., Stanton P. K., Rozental R. (2005): Blockade of gap junctions in vivo provides neuroprotection after perinatal global ischemia. Stroke 36, 2232-2237 http://dx.doi.org/10.1161/01.STR.0000182239.75969.d8

Dupont E., Ko Y., Rothery S., Coppen S. R., Baghai M., Haw M., Severs N. J. (2001): The gap-junctional protein connexin 40 is elevated in patients susceptible to postoperative atrial fibrillation. Circulation 103, 842-849 http://dx.doi.org/10.1161/01.CIR.103.6.842

Elvan A., Huang X. D., Pressler M. L., Zipes D. P. (1997): Radiofrequency catheter ablation of the atria eliminates pacing-induced sustained atrial fibrillation and reduces connexin 43 in dogs. Circulation 96, 1675-1685 http://dx.doi.org/10.1161/01.CIR.96.5.1675

Fontes M. L., Mathew J. P., Rinder H. M., Zelterman D., Smith B. R., Rinder C. S., Multicenter Study of Perioperative Ischemia (McSPI) Research Group. (2005): Atrial fibrillation after cardiac surgery/cardiopulmonary bypass is associated with monocyte activation. Anesth. Analg. 101, 17-23 http://dx.doi.org/10.1213/01.ANE.0000155260.93406.29

Frantseva M. V., Kokarovtseva L., Naus C. G., Carlen P. L., MacFabe D., Perez Velazquez J. L. (2002a): Specific gap junctions enhance the neuronal vulnerability to brain traumatic injury. J. Neurosci. 22, 644-653

Frantseva M. V., Kokarovtseva L., Perez Velazquez J. L. (2002b): Ischemia induced brain damage depends on specific gap-junctional coupling. J. Cereb. Blood Flow Metab. 22, 453-462. http://dx.doi.org/10.1097/00004647-200204000-00009

Hogue C. W. Jr, Palin C. A., Kailasam R., Lawton J. S., Nassief A., Dávila-Román V. G., Thomas B., Damiano R. (2006): C-reactive protein levels and atrial fibrillation after cardiac surgery in women. Ann. Thorac. Surg. 82, 97-107 http://dx.doi.org/10.1016/j.athoracsur.2006.02.043

Jäderstad J., Brismar H., Herlenius E. (2010): Hypoxic preconditioning increases gap-junctional graft and host communication. Neuroreport 21, 1126-1132 http://dx.doi.org/10.1097/WNR.0b013e328340a77b

Jibrini M. B., Molnar J., Arora R. R. (2008): Prevention of atrial fibrillation by way of abrogation of the renin-angiotensin system: a systematic review and meta-analysis. Am. J. Ther. $15,36-43$ http://dx.doi.org/10.1097/MJT.0b013e31804beb59

Kanagaratnam P., Rothery S., Patel P., Severs N. J., Peters N. S. (2002): Relative expression of immunolocalized connexins 40 and 43 correlates with human atrial conduction properties. J. Am. Coll. Cardiol. 39, 116-123
http://dx.doi.org/10.1016/S0735-1097(01)01710-7

Kieken F., Mutsaers N., Dolmatova E., Virgil K., Wit A. L., Kellezi A., Hirst-Jensen B. J., Duffy H. S., Sorgen P. L. (2009): Structural and molecular mechanisms of gap-junction remodeling in epicardial border zone myocytes following myocardial infarction. Circ. Res. 104, 1103-1112 http://dx.doi.org/10.1161/CIRCRESAHA.108.190454

Kostin S., Klein G., Szalay Z., Hein S., Bauer E. P., Schaper J. (2002): Structural correlate of atrial fibrillation in human patients. Cardiovasc. Res. 54, 361-379 http://dx.doi.org/10.1016/S0008-6363(02)00273-0

Kostin S., Schaper J. (2001): Tissue specific patterns of gap junction in adult rat atrial and ventricular cardiomyocytes in vivo and in vitro. Circ. Res. 88, 933-939 http://dx.doi.org/10.1161/hh0901.089986

Laing J. G., Saffitz J. E., Steinberg T. H., Yamada K. A. (2007): Diminished zonula-occludens- 1 expression in the failing human heart. Cardiovasc. Pathol. 16, 169-174 http://dx.doi.org/10.1016/j.carpath.2007.01.004

Lau A. F., Kurata W. E., Kanemitsu M. Y., Loo L. W., Warn-Cramer B. J., Eckhart W., Lampe P. D. (1996): Regulation of connexin 43 function by activated tyrosine protein kinases. J. Bioenerg. Biomembr. 28, 359-368 http://dx.doi.org/10.1007/BF02110112

Li J. Y., Lai Y. J., Yeh H. I., Chen C. L., Sun S., Wu S. J., Lin F. Y. (2009): Atrial Gap Junctions, NF-kB and fibrosis in patients undergoing coronary bypass surgery: the relationship with postoperative atrial fibrillation. Cardiology 112, 81-88 http://dx.doi.org/10.1159/000141012

Lin J. H., Weigel H., Cotrina M. L., Liu S., Bueno E., Hansen A. J., Hansen T. W., Goldman S., Nedergaard M. (1998): Gap-junction-mediated propagation and amplification of cell injury. Nat. Am. Inc. 1, 481-500

Lo B., Fijnheer R., Nierich A. P., Bruins P., Kalkman C. J. (2005): C-reactive protein is a risk indicator for atrial fibrillation after myocardial revascularization. Ann. Thorac. Surg. 79, 1530-1535

http://dx.doi.org/10.1016/j.athoracsur.2004.10.004

Maisel W. H., Rawn J. D., Stevenson W. G. (2001): Atrial fibrillation after cardiac surgery. Ann. Intern. Med. 135, 1061-1073

Mathew J. P., Fontes M. L, Tudor I. C., Ramsay J., Duke P., Mazer C. D., Barash P. G., Hsu P. H., Mangano D. T., Investigators of the Ischemia Research and Education Foundation; Multicenter Study of Perioperative Ischemia Research Group. (2004): A multicenter risk index for atrial fibrillation after cardiac surgery. JAMA 291, 1720-1729

http://dx.doi.org/10.1001/jama.291.14.1720

Matsushita S., Kurihara H., Watanabe M., Okada T., Sakai T., Amano A. (2006): Alterations of phosphorylation state of connexin 43 during hypoxia and reoxygenation are associated with cardiac function. J. Histochem. Cytochem. 54, 343-353 http://dx.doi.org/10.1369/jhc.4A6611.2005

Mühlfeld C., Cetegen C., Freese S., Volkmann R., Hellige G., Vetterlein F. (2010): Phosphorylation of extrajunctional Cx43 in ischemic-preconditioned rat hearts. J. Surg. Res. $162,1-8$ http://dx.doi.org/10.1016/j.jss.2010.02.024 
Nakase T., Fushiki S., Naus C. C. (2003): Astrocytic gap junctions composed of connexin 43 reduce apoptotic neuronal damage in cerebral ischemia. Stroke 34, 1987-1993 http://dx.doi.org/10.1161/01.STR.0000079814.72027.34

Nakase T., Yoshida Y., Nagata K. (2006): Enhanced connexin43 immunoreactivity in penumbral areas in the human brain following ischemia. Glia 54, 369-375 http://dx.doi.org/10.1002/glia.20399

Nao T., Ohkusa T., Hisamatsu Y., Inoue N., Matsumoto T., Yamada J., Shimizu A., Yoshiga Y., Yamagata T., Kobayashi S., Yano M., Hamano K., Matsuzaki M. (2003): Comparison of expression of connexin in right atrial myocardium in patients with chronic atrial fibrillation versus those in sinus rhythm. Am. J. Cardiol. 91, 678-683 http://dx.doi.org/10.1016/S0002-9149(02)03403-3

Nattel S. (2002): New ideas about atrial fibrillation 50 years on. Nature 415, 219-226 http://dx.doi.org/10.1038/415219a

Nattel S. (2004): Age, gender, and supraventricular arrhythmias: roles of ion channels, connexins, and tissue architecture? Heart Rhythm 4, 397-398 http://dx.doi.org/10.1016/j.hrthm.2004.06.012

Orellana J. A., Hernandez D. E., Ezan P., Velarde V., Bennett M. V., Giaume C., Saez J. C. (2010): Hypoxia in high glucose followed by reoxygenation in normal glucose reduces the viability of cortical astrocytes through increased permeability of connexin 43 hemichannels. Glia 58, 329-343

Palatinus J. A., O'Quinn M. P., Barker R. J., Harris B. S., Jourdan J., Gourdie R. G. (2011): ZO-1 determines adherens and gap junctions localization at intercalated disks. Am. J. Physiol. Heart Circ. Physiol. 300, 583-594

http://dx.doi.org/10.1152/ajpheart.00999.2010

Polontchouk L., Haefliger J. A., Ebelt B., Schaefer T., Stuhlmann D., Mehlhorn U., Kuhn-Regnier F., De Vivie E. R., Dhein S. (2001): Effects of chronic atrial fibrillation on gap junction distribution in human and rat atria. J. Am. Coll. Cardiol. 38, 883-891 http://dx.doi.org/10.1016/S0735-1097(01)01443-7

Polontchouk L., Ebelt B., Jackels M., Dhein S. (2002): Chronic effects of endothelin 1 and angiotensin II on gap junctions intercellular communication in cardiac cells. FASEB J. 16, 87-89

Schulz R., Boengler K., Totzeck A., Luo Y., Garcia-Dorado D., Heusch G. (2007): Connexin 43 in ischemic pre- and postconditioning. Heart Fail. Rev. 12, 261-266 http://dx.doi.org/10.1007/s10741-007-9032-3

Sinno H., Derakhchan K., Libersan D., Merhi Y., Leung T. K., Nattel S. (2003): Atrial Ischemia Promotes Atrial Fibrillation in Dogs. Circulation 107, 1930-1936 http://dx.doi.org/10.1161/01.CIR.0000058743.15215.03

Skalidis E. I., Hamilos M. I., Karalis I. K., Chlouverakis G., Kochiadakis G. E., Vardas P. E. (2008): Isolated atrial microvascular dysfunction in patients with lone atrial fibrillation. JACC 51, 2053-2057 http://dx.doi.org/10.1016/j.jacc.2008.01.055

Srisakuldee W., Jeyaraman M. M., Nickel B. E., Tanguy S., Jiang Z. S., Kardami E. (2009): Phosphorylation of connexin-43 at serine 262 promotes a cardiac injury-resistant state. Cardiovasc. Res. 83, 672-681 http://dx.doi.org/10.1093/cvr/cvp142

Takeuchi S., Akita T., Takagishi Y., Watanabe E., Sasano C., Honjo H., Kodama I. (2006): Disorganization of gap junction distribution in dilated atria of patients with chronic atrial fibrillation. Circ. J. 70, 575-582 http://dx.doi.org/10.1253/circj.70.575

Talhouk R. S., Zeinieh M. P., Mikati M. A., El-Sabban M. E. (2008): Gap junctional intercellular communication in hypoxia-ischemia-induced neuronal injury. Prog. Neurobiol. 84, 57-76 http://dx.doi.org/10.1016/j.pneurobio.2007.10.001

Tepass U. (2002): Adherens junctions: new insights into assembly, modulation and function. Bioessays 24, 690-695 http://dx.doi.org/10.1002/bies.10129

Vozzi C., Dupont E., Coppen S. R., Yeh H. I., Severs N. J. (1999): Chamber-related differences in connexin expression in the human heart. J. Mol. Cell. Cardiol. 31, 991-1003 http://dx.doi.org/10.1006/jmcc.1999.0937

Wetzel U., Boldt A., Lauschke J., Weigl J., Schirdewahn P., Dorszewski A., Doll N., Hindricks G., Dhein S., Kottkamp H. (2005): Expression of connexins 40 and 43 in human left atrium in atrial fibrillation of different aetiologies. Heart 91, 166-170 http://dx.doi.org/10.1136/hrt.2003.024216

White S. M., Constantin P. E., Claycomb W. C. (2004): Cardiac physiology at the cellular level: Use of cultured HL-1 cardiomyocytes for studies of cardiac muscle cell structure and function. Am. J. Physiol. Heart Circ. Physiol. 286, 823-829 http://dx.doi.org/10.1152/ajpheart.00986.2003

Wilhelm M., Kirste W., Kuly S., Amann K., Neuhuber W., Weyand M., Daniel W. G., Garlichs C. (2006): Atrial distribution of connexin 40 and 43 in patients with intermittent, persistent, and postoperative atrial fibrillation. Heart Lung Circ. 15, 30-37 http://dx.doi.org/10.1016/j.hlc.2005.06.011

Yeh H. I., Hou S. H., Hu H. R., Lee Y. N., Li J. Y., Dupont E., Coppen S. R., Ko Y. S., Severs N. J., Tsai C. H. (2002): Alteration of gap junctions and connexins in the right atrial appendage during cardiopulmonary bypass. J. Thorac. Cardiovasc. Surg. 124, 1106-1112 http://dx.doi.org/10.1067/mtc.2002.124993

Zeevi-Levin N., Barac Y. D., Reisner Y., Reiter I., Yaniv G., Meiry G., Abassi Z., Kostin S., Schaper J., Rosen M. R., Resnick N., Binah O. (2005): Gap junctional remodelling by hypoxia in cultured neonatal rat ventricular myocytes. Cardiovasc. Res. 66, 64-73 http://dx.doi.org/10.1016/j.cardiores.2005.01.014

Zhou L., Kasperek E. M., Nicholson B. J. (1999): Dissection of the Molecular Basis of pp60v-src Induced Gating of Connexin 43 Gap Junction Channels. J. Cell Biol. 144, 1033-1045 http://dx.doi.org/10.1083/jcb.144.5.1033

Received: October 9, 2011

Final version accepted: January 23, 2012 